The International Journal of Indian Psychology: Volume: 01 | Issue: 04 No. 2 | ISSN 2348-5396

\title{
School Adjustment of Higher Secondary School
}

\author{
Chauhan Ajay.J*, Maniya Anil A**
}

\begin{abstract}
:
The present study was School Adjustment level of Arts and Science students. Total 120 students were selected randomly BHAVNAGAR district area's schools. In which 60 students (30 male and 30 females) from Arts faculty and 60 student (30 male and 30 females) from Science faculty.

After analysis was done according to key for the comparison of difference group ' $t$ ' test was calculated.

\section{INTRODUCTION:}

Students face many adjustments in school. From year to year, there are change in teachers, classrooms, school and class rules and procedures, performance expectations, difficulty of the work and peers. Their successes in negotiating these challenges predict school success.

School adjustment has been construed historically in terms of children 'Academic progress or achievement.(Birch \&laddi 1996) This outcome is important it narrows the search for precursors and events in children's environment that may affect adjustment. One broader level, we might think of adjustment as involving not only children's progress and achievement but also their attitudes toward school anxieties on.

Investigate or have argued that interpersonal relationships affect children's academic motivation (Newman). Contended that involvement or the quality of relationships with peers and teachers is a powerful motivator noted that school learning can be promoted by learning contents that enhance student involvement with of nets. Research shows that children's lone lines and social dissatisfaction related navigation to school achievement.
\end{abstract}

\section{EMOTIONAL DEVELOPMENT}

- Back to school for the shy child :

If you happen to have a school age child who is shy, you are probably all too families

*\&**, MA, Psychology. Sardar Patel University, Vidhyanagar, Gujarat, INDIA
(C) 2014 www.ijip.in
July-September 2014
$120 \mid \mathrm{P}$ a g e 
The International Journal of Indian Psychology: Volume: 01 | Issue: 04 No. 2 | ISSN 2348-5396

with and of spumes worries you. Child may be worrying about the new, kids new classroom and more than likely. You are spending your free time worrying about your child.

The good news is this parent's cam take. Concretesteps to help shy children. In fact according to dr.robert co plan leading shyness.

The goal is never to change children into something they're not co plan says shy children are probably never going to be the most outgoing exuberant people. We're just trying to make sure their shyness doesn't prevent them from doing the kinds of things they need and went to do as a child.

\section{- What is social emotional learning?}

Present expect their children to learn reading, writing and math at school. But after years of measuring success based on test scores, experts are concerned that students arenot learning something just important the social skills they need to successes in life.

According to the national center for education statistics during the 2007 -2008 school year $46 \%$ of public schools had at least one serious disciplinary action and $31 \%$ of schools dealt with fighting or physical attacks in response advocates for social and emotional learning hope to use social skill instruction to address behavior, discipline, safety, and academics to help kids become self-aware, manage their emotions build social skills (empathy perspective talking appreciating differences), from good relationships and make positive decisions.in short says room duffel, executive director of the committee for children 'these are the skills that allow children to calm themselves when angry, make friends, resolve conflicts respectfully and make ethical and safe choices.

\section{- Gender differences :Preschool}

Sugar and spice and everything nice vs.forges and sails and puppy dog tails? The gender differences aren't exactly that clear-cut but by preschool children identify themselves as male or female and gender differences in their four year olds tend to judge others genders based on superficial characteristics assuming for example, that anyone with long hair must be female and that perhaps that persons gender might change with a gender is constant.

Because they are hard wired to enjoy spatial, mechanical play boys require more physical space then girls and will bounce off the walls when.

\section{- Gender differences $: 4^{\text {th }}$ grade}


The International Journal of Indian Psychology: Volume: 01 | Issue: 04 No. 2 | ISSN 2348-5396

A recent study conducted by progress in international reading literacy showed that fourth grade girls in over thirty countries scored higher than boys on reading tests. According to the most recent national assessment of education progress only $21 \%$ of American boys are proficient or advanced writes as opposed to $39 \%$ of girls.

\section{- Your $5^{\text {th }}$ grader's social life}

By fifth grade your child is likely to be ale on mean, social machine and mean. Its matter of survival now is the time when teasing and gossiping take center stage in the social area as children's social instincts become share as a whip and entirely ego centric by fifth grade kids have figured out that to with the social game. You have some 'loser' and fifth graders are anxious to defect criticizing away from themselves exam if that means assigning it to others.

\section{Objectives:}

1. To know the difference between the school adjustment level of male and female students.

2. To know the difference between the school adjustment level of Arts and Science students.

3. To know the difference between the school adjustment level of male and female from Arts group.

4. To know the difference between the school adjustment level of male and female from Science group.

\section{Hypothesis:}

1. There is no difference of school adjustment level of arts male and female.

2. There is no difference of school adjustment level of science male and female.

3. There is no difference of school adjustment level of arts and science male students.

4. There is no difference of school adjustment level of arts and science female students.

5. There is no difference of school adjustment level of male and female students.

\section{Variable:}

In present research following variable are show in this table

\begin{tabular}{|l|c|c|}
\hline \multicolumn{1}{|c|}{ Name of variable } & Nature of variable & Number of variable \\
\hline Two*groups & IV & 2 \\
\hline School adjustment & DV & 1 \\
\hline Gender & IV & 2 \\
\hline
\end{tabular}

IV =Independent Variable, DV =Dependent Variable, ${ }^{*}$ Arts and Science 
The International Journal of Indian Psychology: Volume: 01 | Issue: 04 No. 2 | ISSN 2348-5396

Sampling:

\begin{tabular}{|l|c|c|c|}
\hline \multicolumn{1}{|c|}{ Group } & Male & Female & Total \\
\hline Arts & 30 & 30 & 60 \\
\hline Science & 30 & 30 & 60 \\
\hline- & - & - & - \\
\hline Total & 60 & 60 & 120 \\
\hline
\end{tabular}

Tools:

In the present studies for finding of school adjustment level on the arts and science students the main objectives of this research. percentage score presents study is for finding out the Adjustment test used. Developed by Binna shah and Anashu (1986).

\section{Research design:}

120 male and female students were selected randomly BHAVANAGAR district area's school. Student was divided in two groups. Group one 'Arts', in which 60 persons (30 are male and 30 are female). Number of two group 'Science', in which 60 persons ( 30 are male and 30 are female).

After collecting the data statistical analysis was done according to key for the comparison of different groups ' $t$ ' test was calculated.

\section{Results and Discussion:}

Table no.1: Male and female from Arts group.

\begin{tabular}{|l|c|c|c|c|c|c|}
\hline Groups & N & Mean & SD & SEM & t & Level \\
\hline Male & 30 & 28.50 & 4.37 & 0.80 & 0.7692 & NS \\
Female & 30 & 27.63 & 4.36 & 0.80 & & 0.01 \\
\hline
\end{tabular}

- This table indicates no significant difference between male and female from Arts group. Males are more effective in school adjustment level.

Table no.2: Male and female from Science group.

\begin{tabular}{|l|c|c|c|c|c|c|}
\hline \multicolumn{1}{|c|}{ Group } & $\mathbf{N}$ & Mean & SD & SEM & | & \multicolumn{1}{|c|}{ Level } \\
\hline Male & 30 & 32.23 & 4.62 & 0.84 & 1.3557 & NS \\
Female & 30 & 33.87 & 4.71 & 0.86 & & 0.01 \\
\hline
\end{tabular}


The International Journal of Indian Psychology: Volume: 01 | Issue: 04 No. 2 | ISSN 2348-5396

- This table indicates no significant difference between male and female from science group. Female are more effective in school adjustment level.

Table no.3: Male from Arts and Science group.

\begin{tabular}{|l|c|c|c|c|c|l|}
\hline \multicolumn{1}{|c|}{ Group } & N & Mean & SD & SEM & t & \multicolumn{1}{c|}{ Level } \\
\cline { 1 - 5 } Male (A) & 30 & 28.50 & 4.37 & 0.80 & 3.2154 & NS \\
\cline { 1 - 5 } Female(s) & 30 & 32.23 & 4.62 & 0.84 & & 0.01 \\
\hline
\end{tabular}

- This table indicates no significant difference between male from arts and science group. Science female are more effective in school adjustment.

Table no.4: Female from Arts and Science group.

\begin{tabular}{|l|c|c|c|c|c|c|}
\hline \multicolumn{1}{|c|}{ Groups } & N & Mean & SD & SEM & t & Level \\
\cline { 1 - 5 } Female(A) & 30 & 27.63 & 4.36 & 0.80 & 5.3198 & SIG \\
\cline { 1 - 4 } Female(S) & 30 & 33.87 & 4.71 & 0.86 & & 0.01 \\
\hline
\end{tabular}

- This table indicates significant no difference between female from arts and science group. Science female are more effective in school adjustment.

Table no.5: All over male and female.

\begin{tabular}{|l|c|c|c|c|c|c|}
\hline \multicolumn{1}{|c|}{ Groups } & N & Mean & SD & SEM & t & Level \\
\hline Male & 60 & 28.07 & 4.35 & 0.56 & 6.0289 & SIG \\
Female & 60 & 33.05 & 4.70 & 0.61 & & 0.01 \\
\hline
\end{tabular}

- This table indicates significant no difference between male and female all group. Female are more effective in school adjustment level.

\section{INTERPRETATION OF TABLES AND TESTING OF HYPOTHESIS:}

HO1: There is no significant effect of school adjustment level between male and female of Arts group. Tested $t$ value is 0.7692 at 0.01 levels. So, we accepted of this null hypothesis.

HO2: There is no significant effect of school adjustment level between male and female from Science group. Tested t value is 1.3557 at 0.01 levels. So, we accepted of this null hypothesis.

HO3: There is no significant effect of school adjustment level between male from Arts and Science group. Tested t value is 3.2154 at 0.01 levels. So, we accepted of this null hypothesis. 
The International Journal of Indian Psychology: Volume: 01 | Issue: 04 No. 2 | ISSN 2348-5396

HO4: There is significant effect of school adjustment level between female from Arts and Science group. Tested t value is 5.3198 at 0.01 levels. So, we unaccepted of this null hypothesis.

HO5: There is significant effect of school adjustment level between all over male and female. Tested $t$ value is 6.0289 at 0.01 levels. So, we unaccepted of this null hypothesis.

\section{REFERENCES:}

1. Anderson ,J.E., The psychology of development and personal Adjustment, New York, holt, 1949.

2. Alexander A. Schneider, Personal adjustment and mental health, April 1964, united states of America.

3. Shaffer, L.F, the psychology of adjustment, 1936, Boston: Houghton Mifflin.

4. www.education.com/magazine/article. 